\title{
WELDING OF DEFECTS IN CAST CASES OF TURBINES WITH PERLITE ELECTRODES WITHOUT HEATING AND THERMAL PROCESSING
}

\author{
N.G. Efimenko \\ NTU KhPI, Kharkiv, Ukraine \\ tel. $+38(098) 798-02-70$; \\ S.V. Artyomova \\ Turboatom JSC, Kharkiv, Ukraine \\ E-mail: artemova@turboatom.com.ua; tel. +38(057)349-26-72, +38(063)189-10-45
}

The regularities of structural formation of the weld metal and HAZ during multilayer welding, made by the transverse humping method, with short sections of defects on cast steel 15Kh1M1FL with perlite electrodes without heating and heat treatment are considered. It has been established that the structure of all the studied zones of the welded joint is represented by upper granular bainite of varying degrees of dispersion. The difference in the hardness of the structures in the upper and middle parts of the welded joint is insignificant (3I4 and $296 \mathrm{HV}$, respectively). In the upper part, the formation of a hypereutectoid ferrite is found, which is located along the grain boundaries, which is also related with edge effect. The plastic properties of the weld metal are increased by more than 1.5 times, $\mathrm{KCV}$ - by more than 3 times in comparison with the base metal.

PACS: 62.20.-x; 62.20.Mk; 68.35.Gy; 81.70.Bt

The performance and durability of power equipment is largely dependent on the quality of the hull parts of power units made of heat-resistant steels by casting. Practice has established that the vast majority of defects detected at the manufacturing stage are casting ones [1]: porosity, shrinkage shells, cracks associated with the influence of shrinkage stresses. These defects, as a rule, are most often characteristic of massive thick-walled parts. Single selections of defective places for correction (by welding) often reach 3-5 thousand $\mathrm{cm}^{3}$. The most commonly used universal correction method is manual arc welding. A feature of welding heat-resistant steels is the high metal sensitivity of individual sections of the heat-affected zone (HAZ) heated during welding to the austenization temperature, to various cooling rates below the decomposition temperature of austenite. Upon cooling, solid and brittle structures in these areas of the HAZ are formed. At a certain level of residual welding and structural stresses formed, this leads to the formation of cold cracks. The main way to prevent cold cracking of the HAZ metal is pre-heating and concurrent heating. Depending on the weight of the construction and wall thickness, as well as on the chemical composition of the metal, the heating temperature ranges from 250 to $400{ }^{\circ} \mathrm{C}$, followed by high-temperature tempering of welded joints after welding. Such a technology for correcting casting defects causes production difficulties and is laborintensive, and in some cases impossible.

At one of the stages, when repairing damaged cast parts, the technology of electric arc welding using austenitic electrodes was used [2]. However, during high-temperature operation at the boundary "weld metal - base metal", diffusion processes lead to the formation of brittle martensitic layers, heterogeneity of mechanical properties. To avoid this effect, according to [3], nickelbased electrodes should be used for welding.

The accumulated long-term experience of domestic and foreign researchers has established that a technology with the use of welding materials of the same chemical composition with the base metal as the most promising for welding low-alloy heat-resistant steels is more promising. This technology minimizes undesirable diffusion processes, reduces the microchemical heterogeneity and heterogeneity of mechanical properties in welded joints. At the same time, to reduce the creep rate during high-temperature operation, the carbon content in both cast parts and weld metal should be extremely low $[4,5]$. An increase in carbon content leads to depletion of the solid solution by alloying elements (Cr, Mo), which leads to accelerated creep. To reduce the intensity of diffusion processes, the carbon content is limited. In Russia, VTI scientists have developed and recommended for welding heat-resistant chromium-molybdenum-vanadium steels electrodes of the TML-4B, TML-5 grades [1], which provide a low carbon content in the weld metal $(\sim 0.06 \%)$. This carbon content was obtained by using a low-carbon wire (CB-04A) as a rod, as well as the limited introduction of calcium carbonate $\mathrm{CaCO}_{3}$ into the coating composition. However, a change in the composition of the coating leads to a deterioration of technological properties [1] and, as a result, adversely affects the quality of the weld. An analysis of foreign scientific and practical developments shows that, in order to maintain heat resistance, a decrease in the carbon content in heat-resistant steels and materials for their welding is impractical. So in the USA, pearlitic steels containing $\sim 0.25 \%$ carbon (WCA, WC1, etc.), but with high plastic properties, are used for the power system [1]. High viscous plastic properties are achieved by increasing the purity of the metal in sulfur $(\leq 0.01 \%)$ and phosphorus. To neutralize the negative effects of $S$ and $\mathrm{P}$, rare-earth metals (REM) - cerium ligature are introduced into carbon steel [6]. This increases the plastic properties by $15 \ldots 25 \%$ and impact strength. In Japan, for the welding of chrome-molybdenumvanadium steel, GMB-95 grades are used [7], the deposited metal of which is characterized by a high level of ductility and a low hydrogen content. The 
carbon content is not reduced and is in the range of $0.08 \ldots 0.12 \%$. High plastic properties of the metal are also achieved due to microalloying additives of rareearth metals [6-8].

Thus, from the information presented it follows that the most promising today is the use of weld metal with high viscoplastic properties as a welding material that provides a pearlite structure.

The purpose of the work is to study the structure and mechanical properties of welded joints on steel $15 \mathrm{Kh} 1 \mathrm{M} 1 \mathrm{FL}$, made by the transverse humping method (THM) without heating and subsequent heat treatment with perlite electrodes containing REM (Y) microadditives.

\section{RESEARCH MATERIALS AND METHODS}

We studied welded joints made on massive plates of steel $15 \mathrm{Kh} 1 \mathrm{M} 1 \mathrm{FL}$ with a size of $250 \times 200 \times 110 \mathrm{~mm}$, cast under production conditions. After casting, the plates were subjected to heat treatment according to standard technology. In the middle part of the plates along the long side, the metal was mechanically sampled with a length of $130 \mathrm{~mm}$, a width and depth of $60 \mathrm{~mm}$, simulating a remote defect. The sample was filled by manual arc welding of THM. Welding was performed with UNL-1 electrodes [9] with a diameter of $4 \mathrm{~mm}$ in the mode: $I_{\mathrm{w}}=160 \ldots 170 \mathrm{~A}, U_{\partial}=26 \ldots 27 \mathrm{~B}$. It should be noted that THM provides layer-by-layer formation of a seam with multiple auto-heating with welding heating of each layer of deposited metal. The chemical composition of the weld metal, \%: $\mathrm{C}=0.1 \ldots 0.12 ; \quad \mathrm{Mn}=0.6 \ldots 0.65 ; \quad \mathrm{Si}=0.5 \ldots 0.65 ;$ $\mathrm{Cr}=0.6 \ldots 0.9 ; \mathrm{Mo}=0.5 \ldots 0.7 ; \mathrm{S} \leq 0.012 ; \mathrm{P} \leq 0.019$; REM $(\mathrm{Y})=0.009$; Mechanical properties: Ultimate tensile strength $(\mathrm{UTS})=570 \ldots 580 \mathrm{MPa} ; \sigma_{\mathrm{y}}=$ $400 \ldots 440 \mathrm{MPa} ; \delta=25 \ldots 26 \% ; \psi=68 \ldots 72 \% ; \mathrm{KCV}_{+20}=$ $96 \ldots 100 \mathrm{~J} / \mathrm{cm}^{2}$.

When filling in deep samples, the temperature conditions of the HAZ metal are not the same. Under the influence of thermocyclic influence during layer-bylayer filling, the cooling rates of HAZ sections are also different. Under the conditions of the pronounced influence of the edge effect associated with the limited size of the part, i.e. when barriers arise in the way of heat fluxes, this leads to overheating of the surface local sections of the HAZ metal, the formation of structures, including quenching. Therefore, the HAZ sections were examined at a depth of $10 \mathrm{~mm}$ and $35 \mathrm{~mm}$ from the surface (Fig. 1). The scheme for cutting samples for research is shown in Fig. 2. Toughness KCV was determined on standard samples made from different zones of the welded joint (see Figs. 2, 3). The microstructure was investigated by optical microscopy. Grain boundaries were revealed by etching thin sections in a supersaturated aqueous solution of picric acid with the addition of surfactants. The grain size and its morphology were studied in all zones of the welded joint. In the main and deposited metal (weld), the grain size was estimated by the grid of the boundaries of the ferrite component, and in the high-temperature zone of the HAZ with a predominance of bainite, the grain was determined by the etched grid of the boundaries of the former austenite [10].

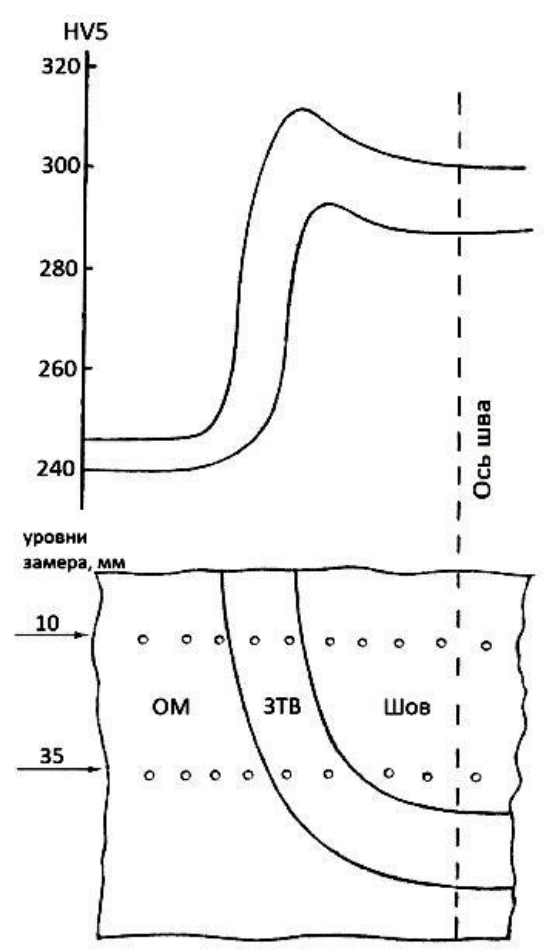

Fig. 1. Measurement scheme (a) and microhardness (b) in various zones of a welded joint

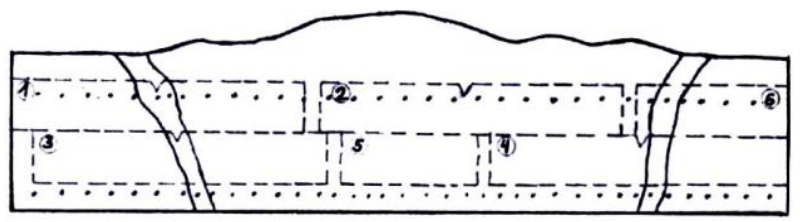

Fig. 2. The scheme for cutting samples for testing

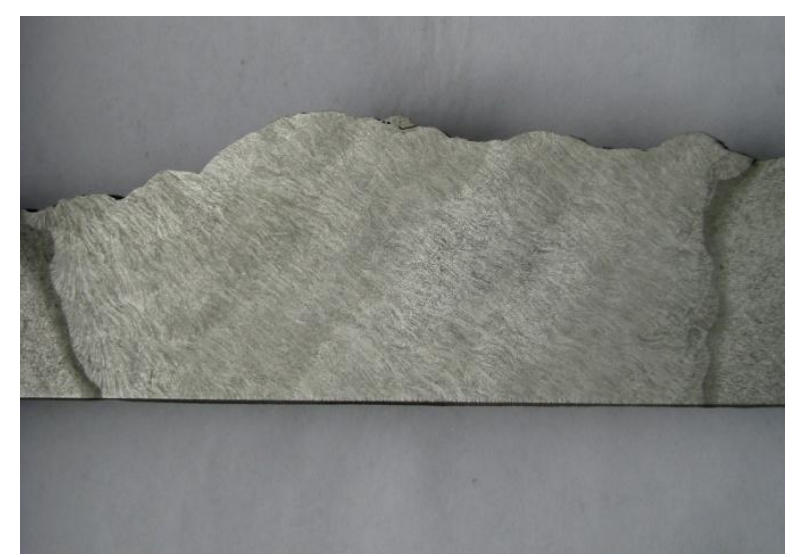

Fig. 3. Macrostructure of a welded joint on steel 15X1M1FL, made by THM

\section{RESEARCH RESULTS}

Evaluation of grain size according to the GOST 5639-82 scale and using quantitative metallography [15] showed that when welding THM, the structure of all areas of the HAZ and weld metal is fine-grained. Especially fine grain in the weld metal $-9,10$ points. In the HAZ, at a distance of up to $3 \mathrm{~mm}$ from the fusion boundary, 8, 9 points; in the HAZ near the fusion boundary $-7,8$ points; in the base metal $-6,7$ points.

It was established that the weld metal of the same type and slightly different from the main chemical composition has a higher hardness of $287 \ldots 303$ and $240 \ldots 250 \mathrm{HV}$ respectively (see Fig. 1). This is 
explained by the modifying effect of REM microadditives contained in the electrode material, as well as by metallurgical processing of deposited metal layers during repeated thermal exposure during layerby-layer filling of the groove. An increase in hardness ( $314 \mathrm{HV})$ observed in the high-temperature region of the HAZ indicates the formation of a nonequilibrium structure. The width of the HAZ with increased hardness reaches $0.5 \ldots 0.7 \mathrm{~mm}$. At a distance of $3.0 \ldots 3.5 \mathrm{~mm}$ from the fusion zone, hardness decreases and reaches the level of $240 \ldots 250 \mathrm{HV}$ (see Fig. 1).

Analysis of the phase composition of the HAZ at different levels along the seam height showed that it is not the same. The increased sensitivity of $15 \mathrm{Kh} 1 \mathrm{M} 1 \mathrm{FL}$ steel to the cooling rate leads to the appearance in the high-temperature heating zone of the HAZ in the upper part of the weld, in addition to granular bainite, structurally-free hypereutectoid ferrite, which is located along the grain boundaries of the former austenite and inside these grains (Fig. 3). It is acceptable that the appearance of ferrite is due to a decrease in the cooling rate and is associated with auto-heating directly from the welding heating, which is provided during LNG welding. According to the MIS classification [11], intragranular ferrite I (PF) is idiomorphic, and the ferrite precipitated along the grain boundaries is referred to as prime ferrite $P F(G)$ ferrite. The light discharge of a rounded shape discovered during the study is separated by grain boundaries and is clearly visible against the background of a bainitic structure (Fig. 4). According to [12], the presence of hypereutectoid ferrite in combination with upper bainite provides $\mathrm{Cr}-\mathrm{Mo}-\mathrm{V}$ steels with an optimal combination of long-term strength and stability, which is associated with the precipitation of dispersed vanadium carbides in ferrite. In addition, the presence of a small amount of ferrite in steel (up to 20\%) increases the plastic properties.

The formation of idiomorphic ferrite is apparently associated with the intragranular structure of austenite, when, under conditions of heating above critical points with small plastic strains in austenite, dynamic in situ processes of crystallization occur [13]. Moreover, in austenitic grains, subgrain boundaries are formed at the joints and along the boundaries of which nuclei I (PF) appear upon cooling. The heating and cooling conditions are such that these ferritic grains do not have time to grow, and the bulk of austenite turns into a granular bainite structure. It is possible that part of ferrite $\mathrm{I}(\mathrm{PF})$ is formed on precipitated dispersed inclusions of secondary phases (vanadium carbides) [13, 14]. It should also be noted that in the middle part of the welded joint, a structure of granular bainite is formed, which has increased etchability. In the HAZ, when approaching the conditional fusion boundary (overheating area), the amount of granular bainite increases and a predominantly finely dispersed granular structure is observed near the boundary (see Fig. 4). These structural changes are provided by auto-heating and thermal cycling during multilayer weld formation and a multiple phase of recrystallization.

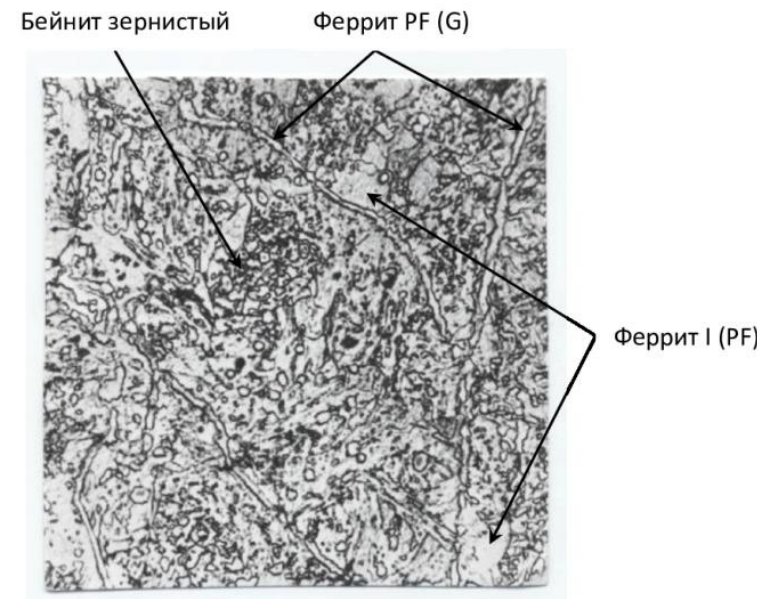

$a$

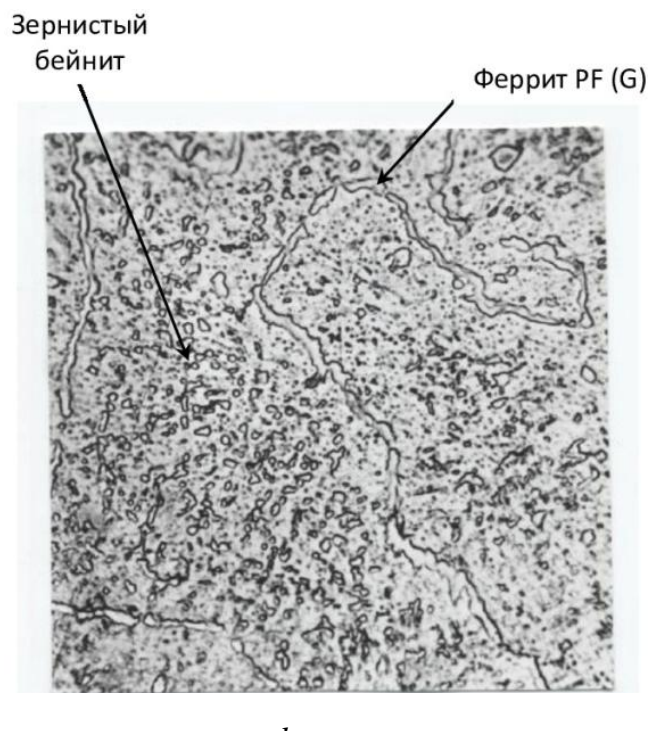

$b$

Fig. 4. Microstructure in the high-temperature region of $H A Z, \times 500$ :

$a$-in the upper part of the weld;

$b$-in the middle part of the weld

Fig. 5 shows the mechanical properties of the metal of various zones of the welded joint. The metal is characterized by high plastic properties. So $\psi$ and $\delta$ have values that are 1.8 and 1.5 times greater than the identical values of the base metal, respectively. Attention should also be paid to the fact that the most dangerous part of the HAZ, characterized by increased hardness (see Fig. 1), has sufficiently high plastic properties (Fig. 5). The microalloying additive of rareearth metals in the welding material ensured high toughness to the weld metal, which is more than 3 times higher than that of the base metal.

A comparative analysis of the results of structural changes, hardness and mechanical properties in the near-surface and middle layers (in depth) of the welded joint did not reveal significant differences. The structure of the upper granular bainite containing up to $20 \%$ of hypoeutectoid ferrite is formed in the HAZ. In the middle layers, a highly dispersed structure with a reduced hardness is formed (see Fig. 1). 


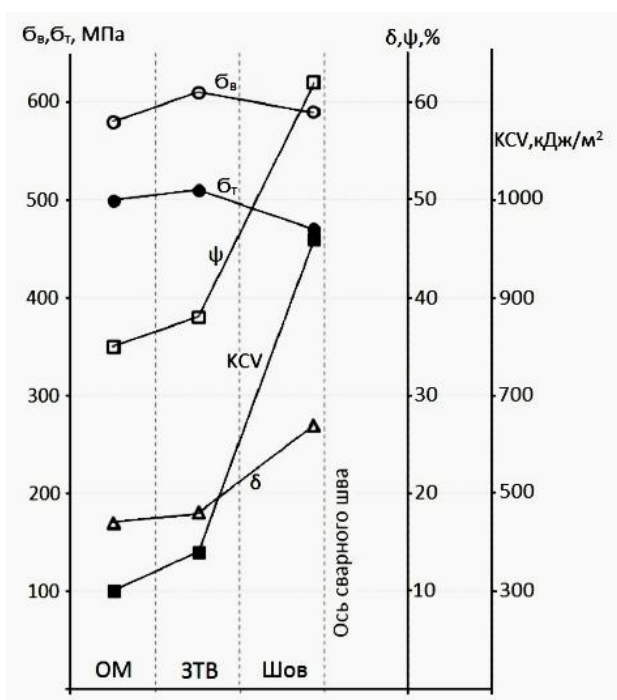

Fig. 5. Mechanical properties of the zones of welded joints on steel 15X1M1FL, made by THM electrodes without heating and heat treatment

Thus, it has been established that the use of pearlite class electrodes with high viscoplastic properties of the deposited metal when welding casting defects on $15 \mathrm{Kh} 1 \mathrm{M} 1 \mathrm{FL}$ steels by the transverse slide method allows to obtain high-quality compounds without preliminary heating and heat treatment after welding.

\section{REFERENCES}

1. А.Е. Анохов, П.М. Корольков. Сварка и термическая обработка корпусного энергетического оборудования при ремонте. Киев: «Экотехнология», 2003, 88 с.

2. В.Н. Земзин, Р.З. Шрон. Термическая обработ-ка и свойства сварных соединений. Л.: «Машиностроение», 1978, 366 с.

3. А.Т. Назарчук, В.В. Снисарь, Э.Л. Демченко. Получение равнопрочных сварных соединений закаливающихся сталей без подогрева и термической обработки // Автоматическая сварка. 2003, №5, c. 41-46.
4. П.А. Антикайн. Металль $u$ расчет на прочность котлов и трубопроводов. М.: «Энергия», 1980, $423 \mathrm{c}$.

5. В.М. Розенберг. Основы жаропрочности металлических материалов. М.: «Металлургия», 1973, $178 \mathrm{c}$.

6. H. Yoshitesu // Newer. Metal. Ind. 1971, v. 16, №5, p. 107-110, №6, p. 133-135.

7. Cobe steel welding consuma bels: Catalog. Tokio, 1978, $103 \mathrm{p}$.

8. А.П. Рычков, К.А. Ланская, Е.И. Тюрин. Влияние РЗМ на структуру и свойства котельных сталей 20К и 12Х1МФ // Сталь. 1973, №10, с. 930932.

9. Н.Г. Ефименко, С.В. Артемова, В.В. Пензев, А.Н. Рожнов. Структура и механико-технологические свойства присадочного материала для сварки теплоустойчивых сталей // Вісник НТУ ХПI. Серія «Енергетичні та теплотехнічні прочеси та устаткування». 2020, №1, с. 43-46.

10. А.c. 281999 СССР, МКП С 23 f 1/00. Реактивы для выявления грании зерен в закаленных сталях / А.В. Сахарова, Н.А. Радзивилова, Г.И. Михайленко. Опубл. 14.09.70; Бюл. №29, №116590/22-1.

11. Е.Л. Шейнман. Классификация микроструктуры сталей Международного института сварки // Сварочное производство. 2006, №7, с. 33-37.

12. К.А. Ланская, Л.В. Куликова, В.В. Яровой. Микролегирующие и примесные элементы в низколегированной Cr-Mo-V-стали. М.: «Металлургия», 1989, $176 \mathrm{c.}$

13. С.С. Горелик. Рекристаллизация металлов и сплавов. М.: «Металлургия», 1967, 401 с.

14. Б.А. Дроздовский, Я.Б. Фридман. Влияние трещин на механические свойства конструкциионных сталей. М.: ГНТИ, Литература по черной и цветной металлургии, 1960, 260 с.

15. С.А. Салтыков. Стереометрическая металлография. М.: «Металлургия», 1970, 375 с.

Article received 25.06.2020

\section{ЗАВАРКА ДЕФЕКТОВ В ЛИТЫХ КОРПУСНЫХ ДЕТАЛЯХ ТУРБИН ПЕРЛИТНЫМИ ЭЛЕКТРОДАМИ БЕЗ ПОДОГРЕВА И ТЕРМИЧЕСКОЙ ОБРАБОТКИ}

\section{Н.Г. Ефименко, С.В. Артемова}

Рассмотрены закономерности структурообразования металла шва и зоны термического влияния (3ТВ) при многослойной заварке короткими участками дефектов на литой стали 15Х1М1ФЛ перлитными электродами способом поперечной горки (СПГ) без подогрева и термической обработки. Установлено, что структура всех исследуемых зон сварного соединения представлена верхним зернистым бейнитом различной степени дисперсности. Разница в твердости структур в верхней и средней частях сварного соединения незначительна (314 и $296 \mathrm{HV}$ соответственно). В верхней части обнаружено формирование доэвтектоидного феррита, располагающегося по границам зерен, что связано, в том числе, с краевым эффектом. Пластические свойства металла шва увеличены более чем в 1,5 раза, $\mathrm{KCV}$ - более чем в 3 раза по сравнению с основным металлом. 


\section{ЗАВАРКА ДЕФЕКТІВ У ЛИТИХ КОРПУСНИХ ДЕТАЛЯХ ТУРБІН ПЕРЛІТНИМИ ЕЛЕКТРОДАМИ БЕЗ ПІДІГРІВУ ТА ТЕРМІЧНОЇ ОБРОБКИ}

М.Г. Сфіменко, С.В. Артьомова

Розглянуто закономірності структуроутворення металу шва і зони термічного впливу (ЗТВ) при багатошаровій заварці короткими ділянками дефектів на литій сталі 15X1M1ФЛ перлітними електродами способом поперечної горки (СПГ) без підігріву і термічної обробки. Встановлено, що структура усіх досліджуваних зон зварного з'єднання представлена верхнім зернистим бейнітом різної міри дисперсності. Різниця в твердості структур у верхній і середній частинах зварного з'єднання незначна (314 і $296 \mathrm{HV}$ відповідно). У верхній частині виявлено формування доевтектоїдного фериту, розташованого по межах зерен, що пов'язано, в тому числі, з крайовим ефектом. Пластичні властивості металу шва збільшені більш ніж у 1,5 рази, KCV - більш ніж у 3 рази в порівнянні з основним металом. 